\title{
Laterally positioned flap using subepithelial connective tissue graft for iatrogenic gingival recession treatment
}

\author{
Sung-Jo Lee* \\ Department of Periodontology, College of Dentistry, Dankook University, Cheonan, Republic of Korea
}

Gingival recession could occur after orthodontic or endodontic treatment. This could influence not only functional and aesthetic problem, but also patient's treatment satisfaction. There are a lot of techniques for preventing gingival recession, but laterally positioned flap with subepithelial connective tissue graft could get definite advantages such as increase of keratinized gingival width and harmonious color match between graft tissue and surrounding tissue. Clinician should select a right patient case and diagnosis with clinical and radiography exam. In a surgical procedure, getting enough amounts of subepithelial connective tissue and flap coverage should be taken into consideration. The clinical outcomes in this case report shows laterally positioned flap with subepithelial connective tissue graft could be a treatment with predictive outcome. (J Dent Rehabil Appl Sci 2016;32(4):330-7)

Key words: iatrogenic disease; gingival recession; surgical flaps; connective tissue; transplantation

\begin{abstract}
서론
치은 퇴축의 직접적인 원인으로는 과도한 칫솔질, 재발 성 염증, 열상, 의원성 요소가 있다. ${ }^{1}$ 이들 원인 중 의원성 치은퇴축(iatrogenic gingival recession)은 교정치료에 의 한 치은 퇴축이 대표적이며, 근관치료 중 발생된 과도한 기구조작에 의한 치근 천공에 의해서도 발생될 수 있다. 교정치료에 의한 치은퇴축의 원인으로 얇은 치은과 교정 력에 의한 치아의 과도한 협측 변위, 브라켓 및 와이어 등 의 치태 및 치면 세균막에 의한 치은염의 심화 등으로 알 려져 있다. ${ }^{2}$ 근관치료에 의한 치근 천공으로 인한 치은퇴 축은 흔치 않으나, Seltzer 등은 근관치료 중에 일어나는 치근 천공 시 치주조직의 염증, 치주인대의 파괴, 골흡수, 치주낭 형성, 그리고 치은퇴축이 발생할 수 있다고 보고 한 바 있다. ${ }^{3}$
\end{abstract}

Miller는 치은퇴축을 4가지로 분류하였는데, I급은 치

*Correspondence to: Sung-Jo Lee

Postgraduate Student, Department of Periodontology, College of Dentistry, Dankook University, 119, Dandae-ro, Dongnam-gu, Cheonan, 31116, Republic of Korea Tel: +82-41-550-0263, Fax: +82-303-3442-7364, E-mail: periolee85@gmail.com Received: December 7, 2016/Last Revision: December 15, 2016/Accepted: December 17, 2016
은퇴축이 치은치조점막 경계(mucogingival junction)까 지 도달하지 않은 상태, II급은 치은퇴축이 치은치조점막 경계에 인접하나 부착소실 및 연조직, 골조직의 파괴가 없는 경우, III급은 치은치조점막 경계에 인접한 치은퇴 축 및 치간부위에 한정된 부착소실을 타나낼 때 그리고 $\mathrm{IV}$ 급은 치은치조점막 경계까지 연장된 치은 퇴축이 심각 한 연조직 및 골조직의 소실을 동반할 때로 설명하였다. ${ }^{4}$ 치은퇴축을 극복하기 위한 다양한 방법의 치근 피개술 이 존재하며 술식에 따른 장단점이 있으나 술식의 종류와 관계없이 Miller의 분류 I, II급에서는 $100 \%$ 의 치은 피개 를 이루어야 한다. 1956년 Grupe에 의해 소개된 측방변 위판막술은 인접 치은에 충분한 부착치은이 존재하는 단 독으로 발생한 좁은 치은 퇴축 치료에 용이한 술식으로 판막의 유연성과 예지성 있는 각화치은을 얻을 수 있다는 장점이 있으며 최대 $96 \%$ 의 유의성 있는 평균 치근 피개 율(mean root coverage)을 얻을 수 있음이 보고 되었다. ${ }^{5-7}$

Copyright@ 2016 The Korean Academy of Stomatognathic Function and Occlusion. (c) It is identical to Creative Commons Non-Commercial License. 
Zucchelli는 그의 저서에서 측방변위판막술의 시행 시 필요한 공여부 및 수여부의 특징과 판막의 형성에 대 해 저술하였다. 공여부는 노출된 치근의 백악법랑경계 (cementoenamel junction)에서 측정된 폭경에 최소 6 $\mathrm{mm}$ 근원심으로 연장된 폭을 지녀야하고, 치관-치근방향 으로 최소 $1 \mathrm{~mm}$ 의 부착치은과 $2 \mathrm{~mm}$ 의 각화치은이 존 재해야하며, 최소 $1 \mathrm{~mm}$ 의 두께의 각화조직이 존재해야 한다고 설명하였다. 수여부는 노출된 치근의 근원심부 에 각각 $3 \mathrm{~mm}$ 의 수평절개를 하고, 수직절개는 노출된 치 근의 근심치은변연과 평행해야하며, 노출된 치근의 원심 치은변연에서 열구 내 사면절개를 시행하며 이를 연장시 켜 근심 수직절개와 연결시킨다고 설명하였다. 판막은 부 분층과 전층의 혼합형태로 형성하는데, 노출된 치근면에 닿는 판막의 중심부는 전층판막, 그 외의 부분은 부분층 판막을 형성한다고 설명하였다(Fig. 1). ${ }^{8}$

또한 치은 퇴축의 치료 시 유리치은 이식과 상피하결합 조직 이식을 동반한 술식을 고려할 수 있는데, 상피하결 합조직 이식술은 유리치은 이식술에 비해 이식편에 대한 우수한 혈류 공급, 구개 공여부의 빠른 치유 및 적은 술 후 불편감, 인접조직과의 조화로운 색조, 얇은 치은에도 성공적인 치근피개 가능 등의 장점을 갖는다 보고 되었 다. ${ }^{9}$ Lee 등은 교정치료 후 발생된 Miller의 분류 III급의 치은 퇴축 발생 환자에게 상피하결합조직 이식을 동반한 측방변위판막술을 시행 했을 때 $78 \%$ 의 치근피개를 보고 하였다. ${ }^{8}$ Carnio와 Neiva는 근관치료 중 의원성 치근 천 공으로 인해 치은 천공 및 골 열개가 발생한 환자에게 상 피하결합조직 이식을 동반한 측방변위판막술을 시행했
을 때 최대 6년간의 추적관찰시 성공적이었다 보고한 바 있다. ${ }^{10}$ 정 등도 근관치료 중 가열된 plugger로 인해 치은 괴사와 치조골 노출이 발생한 두 환자에게 동일한 술식 으로 성공적인 치근피개를 이루었다. ${ }^{11}$

따라서 본 증례에서는 상피하결합조직 이식을 동반한 측방변위판막술을 통해 의원성 치은퇴축을 치료한 사례 를 보고하고자 한다.

\section{증례 보고}

\section{1. 증례 1}

20세의 여성환자가 아래쪽 잇몸이 내려가 있다는 주소 로 내원하였다. 1년 전 교정치료를 완료한 상태로 임상 적 및 방사선학적 검사 결과 하악 좌측 중절치의 $2 \mathrm{~mm}$ 의 치은퇴축, $3 \mathrm{~mm}$ 의 임상적 부착 수준(clinical attachment level) 그리고 각화치은 결손을 나타내어 Miller의 분류 II 급으로 진단하였다(Fig. 2).

하악 좌측 중절치 근심 치근단부위에 부분층의 수여부 를 형성하였고, 인접 측절치의 치근단 부위에 공여부를 형성하였다. 동측 상악 구개측에서 상피하결합조직을 8 $\times 3 \times 1 \mathrm{~mm}$ 의 크기로 채득하고 수여부에 6-0 흡수성 봉 합사(Coated vicryl 6-0, Ethicon Inc., Somerville, USA) 로 봉합하여 고정시킨 뒤, 하악 좌측 측절치 치근단 부위 의 공여부 판막을 근심으로 이동시켜 5-0 비흡수성 봉합 사(Ethilon 5-0, Ethicon Inc.)로 봉합하였다. 상악 구개 측 공여부 및 대구개 혈관도 5-0 비흡수성 봉합사로 간접
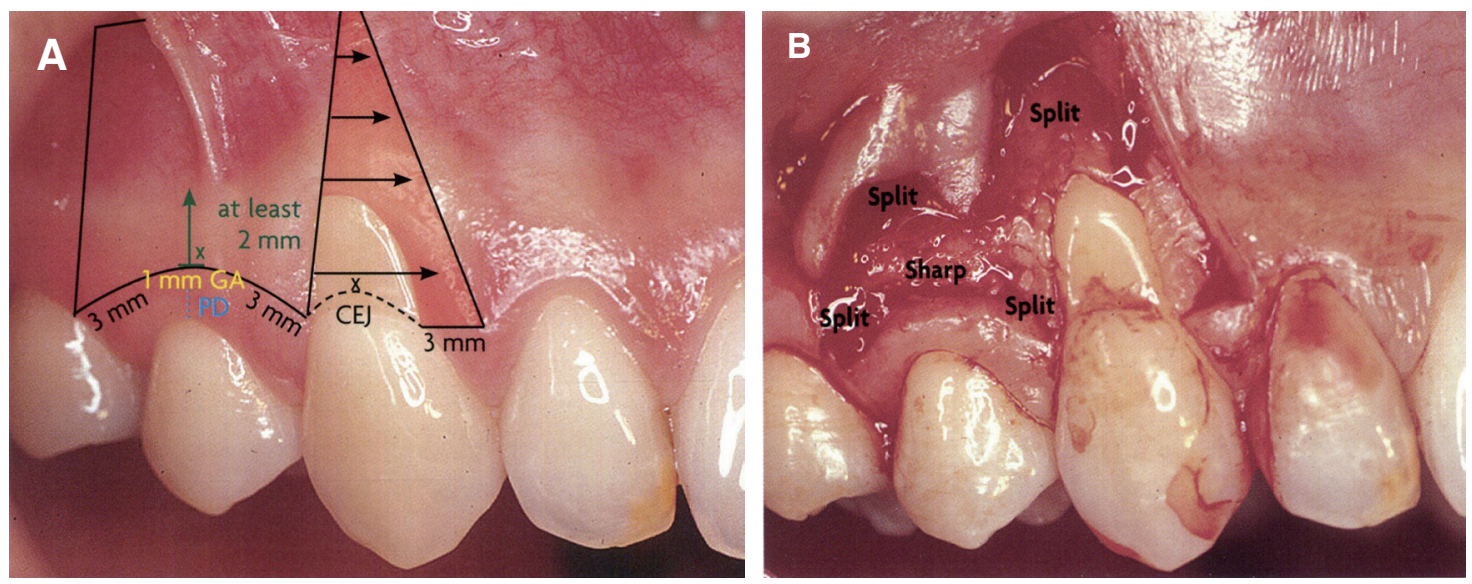

Fig. 1. (A) Donor \& recipient site design, (B) Mix-thickness flap. CEJ, cementoenamel junction; Split, split-thickness flap; Sharp, sharp horizontal incision \& full-thickness flap. 

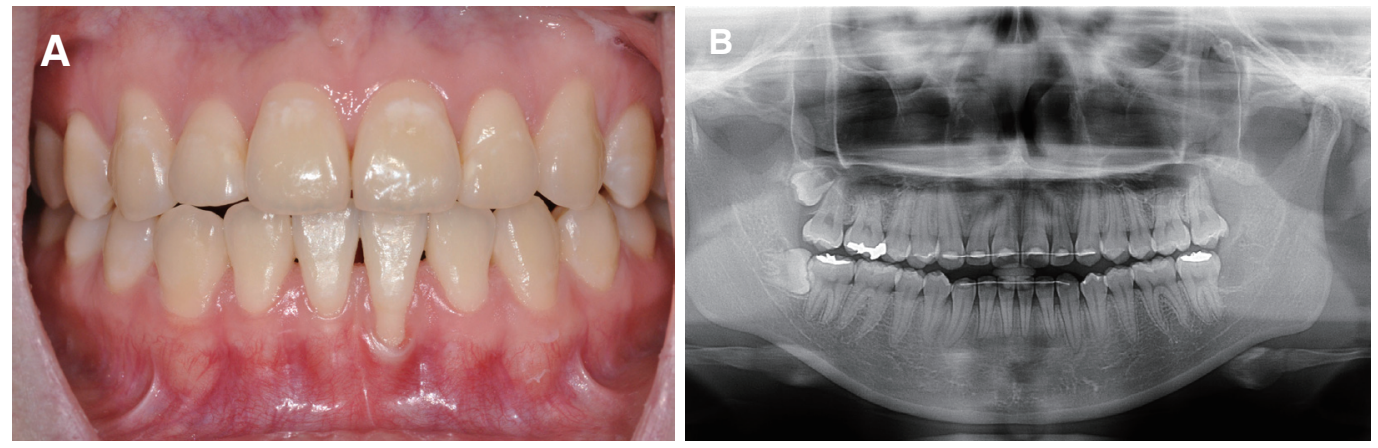

Fig. 2. (A) Initial aspect of Case I showing Miller Class II localized gingival recession at the mandibular left central incisor, (B) Panoramic radiography of Case I.
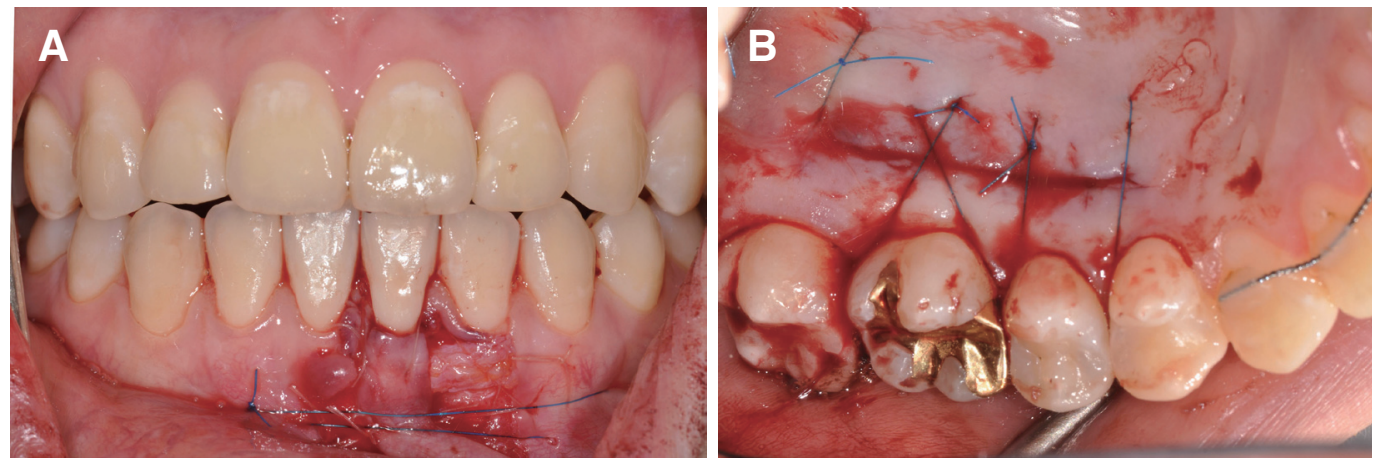

Fig. 3. Clinical view of surgical procedure. (A) A lateral flap was positioned over the connective tissue graft and sutured, (B) Palatal donor site was sutured.
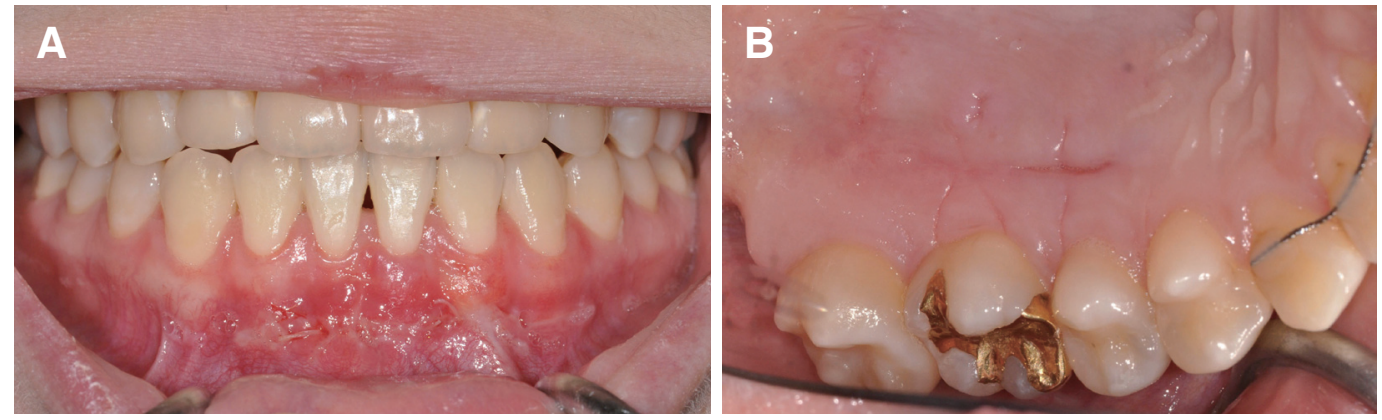

Fig. 4. Postoperative clinical view after 15 days. (A) Stable healing observed at recipient site and (B) palatal donor site.

봉합 시행하였다(Fig. 3).

15일 후 발사 시행하였고 주변 치은과의 조화가 양호 한 $100 \%$ 의 치근피개를 얻을 수 있었으며 구개측 공여부 의 양호한 치유양상을 나타내었다(Fig. 4). 술 후 3개월의 치근피개량은 시술 직후와 유사한 수준으로 유지 되었으 며, 임상적 부착 수준은 약 $1 \mathrm{~mm}$ 로 측정 되었다(Fig. 5).

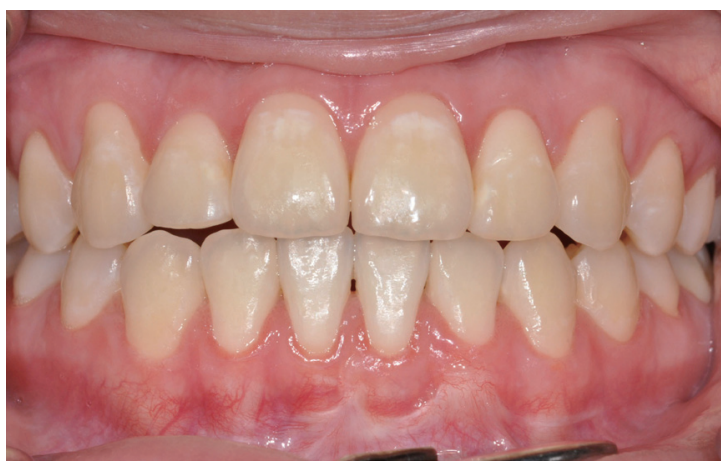

Fig. 5. After 3 months clinical view of Case I. 


\section{2. 증례 2}

26세 여성환자가 신경치료 한 곳 코 부위가 뻐근하고 잇몸이 낫지 않는다는 주소로 내원하였다. 상악 좌측 측 절치의 이차우식으로 인해 근관치료를 진행하여 본원 내 원 일주일 전 완료한 상태였다. 임상적 및 방사선학적 검 사 결과 근관충전 중 발생된 과도한 열로 인한 골괴사 및 부골형성을 동반한 치은퇴축으로 Miller의 분류 II급으 로 진단하였다(Fig. 6).

부골 적출술(Sequestrectomy)을 위해 판막을 거상 하였고, 퇴축된 치은 변연부에 골소주 양상(trabecular pattern)이 보이지 않는 부골이 관찰되었다. 노출된 부골 을 삭제한 후 6-0 비흡수성 봉합사(Ethilon 6-0, Ethicon Inc.)로 봉합 완료하였다(Fig. 7). 15일 후 발사하였으며, 삭제한 골의 치유를 위해 수술 후 4달 뒤 치근피개술을 시행하였다.
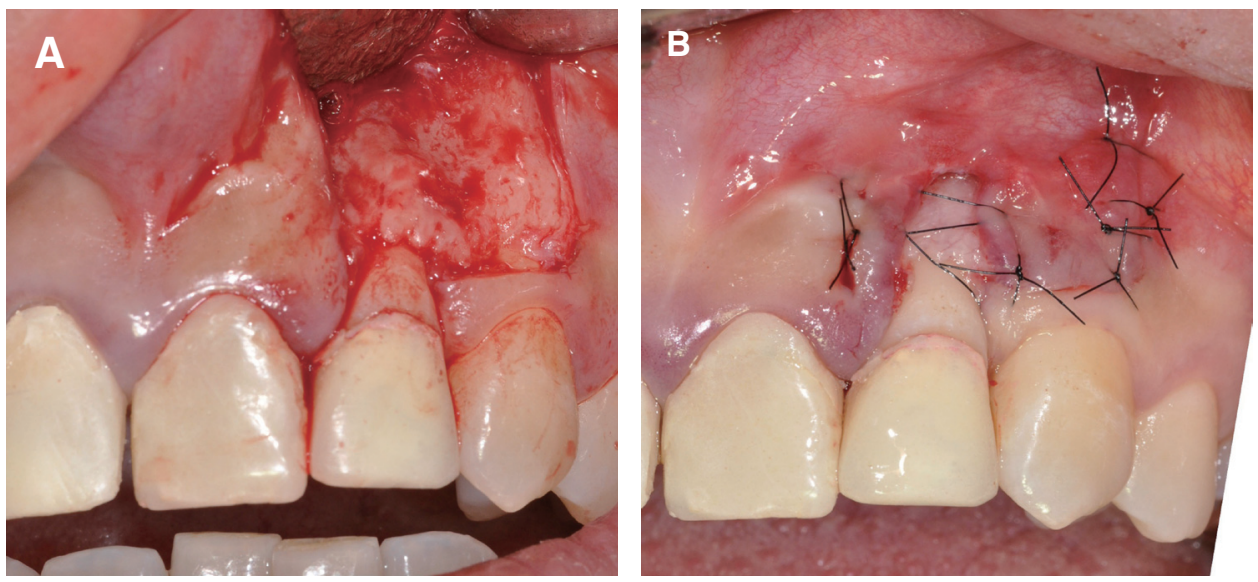

Fig. 7. Clinical view of surgical procedure for sequestrectomy. (A) Sequestrum observed below the recessed gingival margin, (B) Suture after trimming sequestrum.
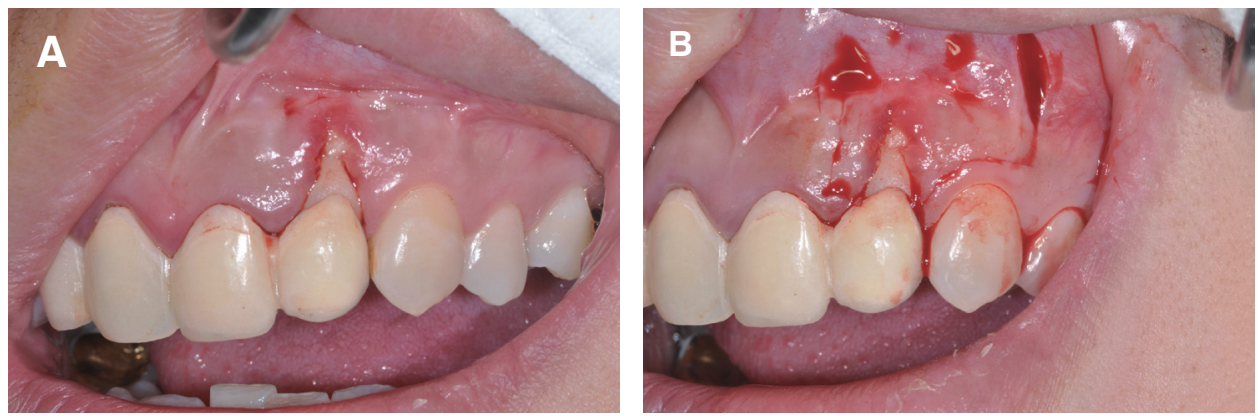

Fig. 8. Clinical view of surgical procedure. (A) Showing $3 \mathrm{~mm}$ gingival receesion, (B) Partial thickness flap incision making for recitient site. 

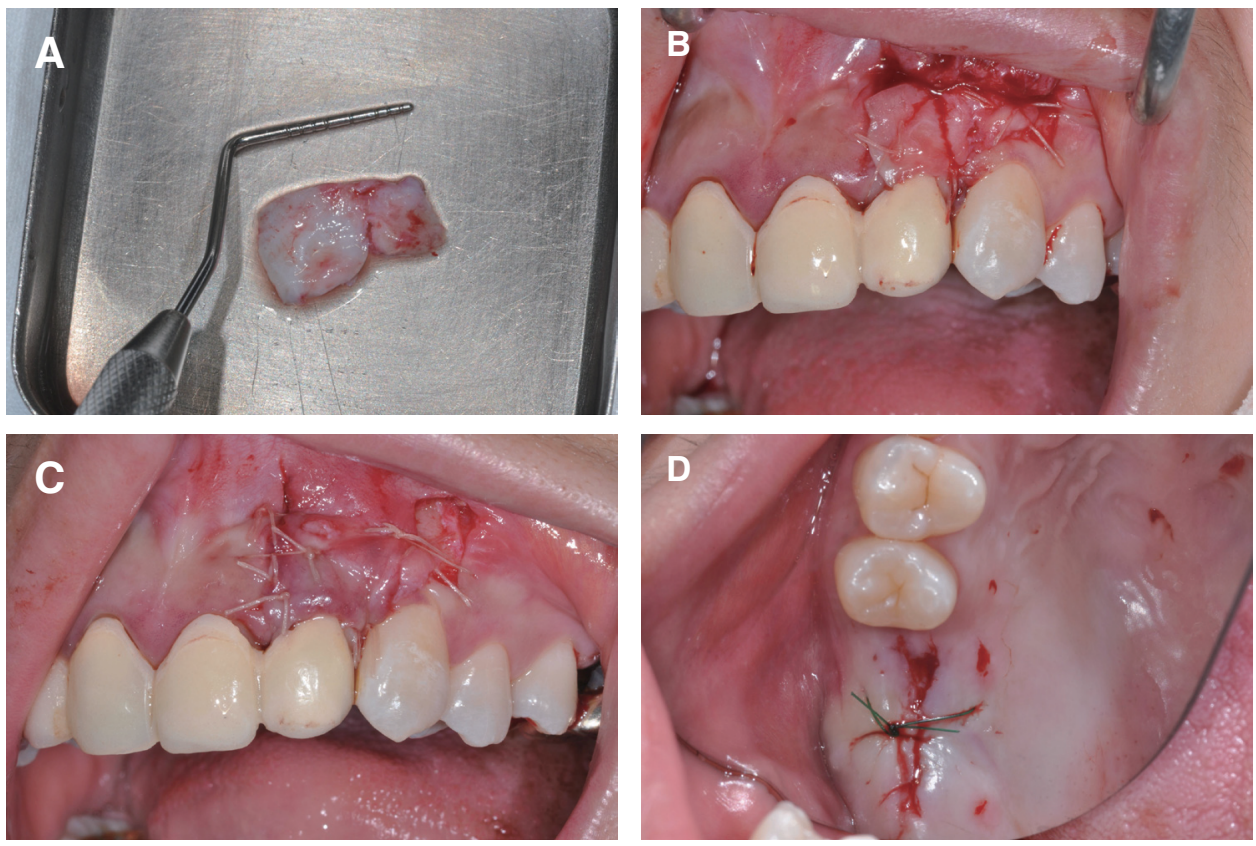

Fig. 9. Clinical view of surgical procedure. (A) Subepithelial connective tissue grafting from edentulous ridge, (B) The graft tissue positioned at recipient site, (C) A lateral flap was positioned over the connective tissue graft and sutured, (D) Edentulous donor site was sutured.
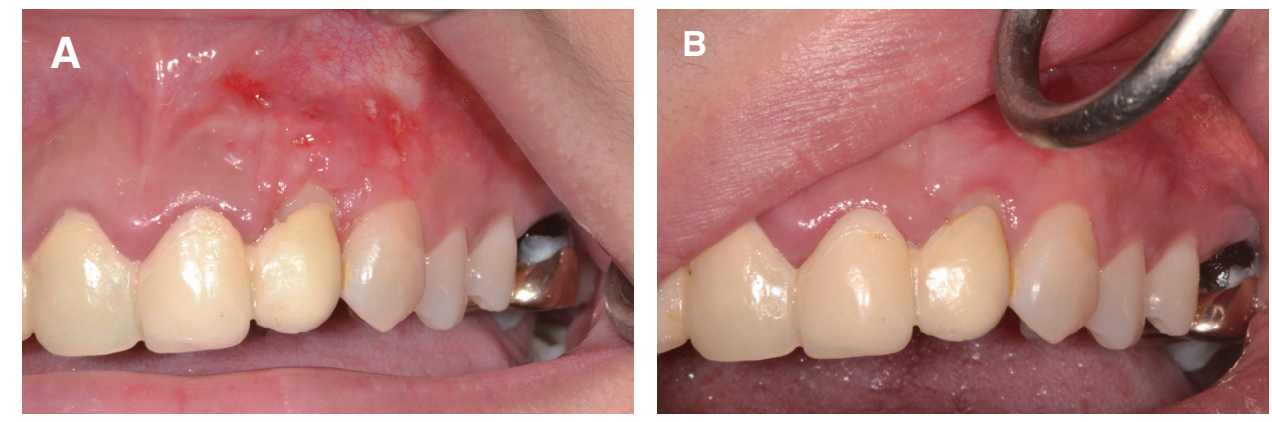

Fig. 10. (A) Postoperative clinical view after 15 days and (B) after 3 months. $1 \mathrm{~mm}$ gingival recession remained.

합조직을 $13 \times 8 \times 2 \mathrm{~mm}$ 의 크기로 채득하고 수여부에 4-0 흡수성 봉합사(Coated vicryl 4-0, Ethicon Inc.)로 봉 합하여 고정시킨 뒤, 상악 좌측 견치 치근단 부위의 공여 부 판막을 근심으로 이동시켜 4-0 흡수성 봉합사로 봉 합하였다. 상악 구개측 공여부는 4-0 비흡수성 봉합사 (Happylon 4-0, Shirakawa Co., Takayama, Japan)로 봉 합 시행하였다(Fig. 9).

15 일 후 발사 시행하였고 주변 치은과의 조화가 양호 한 상태이나 백악법랑경계 하방 약 $1 \mathrm{~mm}$ 의 치근이 피개 되지 않았다. 구개측 공여부의 양호한 치유양상을 보였 으며 견치 치근단 공여부위의 치은퇴축도 일어나지 않았 다. 술 후 3 개월의 치근피개량은 시술 직후와 유사한 수 준으로 유지되었으며, 임상적 부착 수준은 약 $2 \mathrm{~mm}$ 로

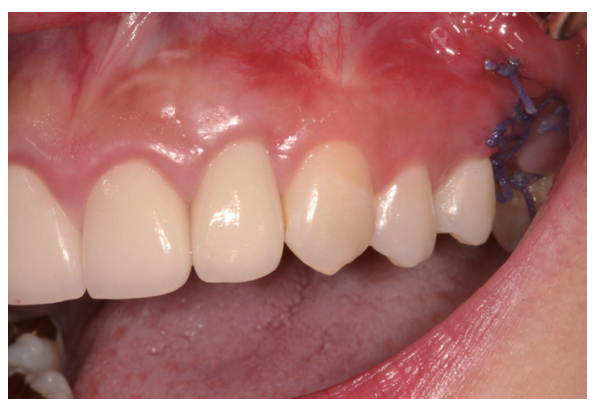

Fig. 11. After 1 year clinical view of Case II.

측정되었다(Fig. 10). 이후 보철물 제재작을 통해 노출되 어있는 치근을 피개하였고 1 년 후 점검 시 치아 및 치은 의 조화로운 형태가 유지 되었다(Fig. 11). 


\section{고찰}

치은퇴축을 치료하기 위한 치근피개술식은 다양하게 보고되고 있는데 크게 유경판막 이식술과 유리판막 이 식술로 분류할 수 있으며 혈관이 없는 치근 표면에 이식 된 판막의 생존률을 높일 수 있도록 혈행이 지속되는 유 경판막 형태의 술식들이 선호된다. ${ }^{12,13}$ 유경판막 이식술 에 해당하는 치관변위판막술과 측방변위판막술은 수여 부 연조직과의 색조, 형태 등의 조화를 이루기 좋고 성공 률이 높은 것으로 알려져 있다. ${ }^{14}$ 두 가지 술식에 대한 많 은 비교 연구가 있었고 그 결과 또한 다양했으나, 2010년 Santana 등은 치관변위판막술과 측방변위판막술의 비교 연구에서 측방변위판막술이 술 후 획득되는 각화치은의 양이 유의성이 있게 많다고 보고하였다. ${ }^{15}$ 본 증례들은 수여부의 각화치은량이 매우 부족한 상태로, 그 양의 증 가를 도모하기 위해 측방변위술식을 선택하게 되었다.

Zucchelli 등은 maximum root coverage (MRC)의 개 념에 대해 소개했는데, 치은퇴축 및 국소적 요인으로 인 해 해부학적 백악법랑경계의 위치를 확인하기 어려울 경 우 술 후 $\mathrm{MRC}$ 를 예측할 수 있는 가상선을 설정할 필요 성이 있다고 하였다. 이를 위해 cementoenamel junction point angle (CPA)에 대해 설명하였는데 이는 마모로 인 해 존재하지 않는 협측 백악법랑경계가 아닌 치간유두에 가려진 인접면 하방의 백악법랑경계와 협측 치은이 만나 는 점을 의미한다. 해당 마모치아의 근원심 $\mathrm{CPA}$ 간 기존 백악법랑경계의 scallop형태로 연결된 가상선이 예측 가 능한 MRC라 설명하였다. 또한 치간유두가 퇴축되어 있 는 경우도 $\mathrm{MRC}$ 를 예측할 수 있다 보고하였는데, 퇴축이 일어난 치아와 인접 정상치아의 $\mathrm{CPA}$ 를 수평으로 이은 가상선에서 두 치아의 접촉점(contact point)까지의 길이 가 이상적인 치간유두의 높이(ideal papilla height)이므로 퇴축된 치간유두의 tip에서 이상적 치간유두의 높이만큼 내려간 위치까지만 $\mathrm{MRC}$ 가 가능하다 설명하였다. ${ }^{16}$

결합조직의 채득 부위는 전치부 구개측, 구치부 구개 측, 그리고 상악 결절부위 세가지로 분류될 수 있다. 수여 부의 위치는 술자의 선호도에 따라 달라질 수 있으나, 전 치부 구개측의 상피하결합조직의 경우 조직밀도가 구개 측에 비해 떨어져 혈행공급이 유리하여 이식편의 생존률 은 높으나 술 후 수축률이 높아 예지성이 떨어진다. 구개 측과 상악 결절부위의 조직은 밀도가 높아 생존률은 낮 을 수 있으나 술 후 수축률이 낮아 예지성 있는 치료가 가능해진다. 따라서 구개측의 결합조직을 사용할 경우
판막으로 최대한 피개하여 혈행을 공급하는 것이 유리하 다. ${ }^{17}$ 적절한 이식편 크기 및 두께에 대해 Yotnuengnit 등 은 $100 \%$ 의 치근피개율을 얻기 위해서 노출된 치근 주변 조직으로 최소한 $3-5 \mathrm{~mm}$ 확장되거나, 노출된 치근면보 다 최소 11 배 넓은 이식편을 채득할 것을 추천하였으며, ${ }^{18}$ Langer 와 Langer는 $1.5 \mathrm{~mm}$ 가 이식편의 이상적인 두께 라고 하였다. 또한 이식편 상방의 판막의 피개량에 대해 설명하였는데 노출된 치근면 위의 유일한 혈류 공급원으 로서 $1 / 2-2 / 3$ 를 피개할 것을 추천하였다. ${ }^{19}$ 본 증례에 서 사용된 이식편들은 $1-2 \mathrm{~mm}$ 의 두께와 노출된 치근면 근원심 조직으로 $3-5 \mathrm{~mm}$ 확장된 폭경을 지녀 이상적인 형태에 완벽히 부합하진 않으나, 이식편 전체를 판막으 로 피개하여 원할한 혈행공급을 통해 이식편의 생존률을 높여 긍정적인 결과를 얻어냈다 사료된다.

Miller는 치근 피개의 성공 기준에 대해 백악법랑경계 까지의 치근 피개, 탐침 깊이 $2 \mathrm{~mm}$ 이하, 탐침 시 출혈 없 음, 적절한 각화치은대 형성, 적절한 색조화, 심미적 조 직 형태 그리고 지각과민의 감소라 제시하였다. ${ }^{20}$ 증례 1 에서는 좌측 견치부위의 치은치조점막 경계가 약간 치관 부위로 이동되면서 점막치유양상이 관찰되었다. 그러나 적절한 양의 각화치은 형성에 성공하였고 그 외의 성공 기준에 모두 부합하므로 성공적인 증례라 할 수 있었다. 증례 2에서는 완전한 치근피개가 이루어지지 못하였고 보철물 재제작을 통해 마무리되었다. 이는 앞서 설명한 $\mathrm{MRC}$ 개념으로 설명 가능한데, 기존 보철물의 낮은 접촉 점과 더불어 해당치아의 퇴축된 치간유두에 의해 $\mathrm{MRC}$ 가 가능한 높이가 해부학적 백악법랑경계보다 낮아졌다 해석된다. 그러나 색조조화, 적절한 각화치은대, 민감도 감소 등의 측면에서 성공적이라 볼 수 있었다. 또한 두가 지 증례 모두 수여부의 반흔 형성 없이 치유 되었다. 추 후 지속적인 관찰 및 다양한 증례에서의 치료 및 연구가 필요로 하나 위 두가지 증례로 미루어 볼 때 상피하결합 조직 이식술을 동반한 측방변위판막술은 의원성 치은퇴 축 환자에 있어서 선택 가능한 치료법으로 사료된다.

\section{결론}

의원성 손상으로 인한 치은퇴축은 심미적, 기능적 손 상을 주고 치료의 만족도를 떨어뜨릴 수 있다. 환자의 상 태에 대한 방사선학적 및 임상적 검사를 시행하여 치근 피개술을 통한 회복 가능성이 높을 것으로 진단 된 경우 (Miller의 분류 I, II급), 상피하결합조직 이식술을 동반한 
측방변위판막술은 예지성 있는 결과를 나타낼 수 있다.

\section{ORCID}

Sung-Jo Lee http://orcid.org/0000-0002-7834-209X

\section{References}

1. Hall WB. Present status of soft tissue grafting. J Periodontol 1977;48:587-97.

2. Melsen B, Allais D. Factors of importance for the development of dehiscences during labial movement of mandibular incisors: a retrospective study of adult orthodontic patients. Am J Orthod Dentofacial Orthop 2005;127:552-61.

3. Seltzer S, Sinai I, August D. Periodontal effects of root perforations before and during endodontic procedures. J Dent Res 1970;49:332-9.

4. Miller PD Jr. A classification of marginal tissue recession. Int J Periodontics Restorative Dent 1985;5: 8-13.

5. Grupe HE, Warren RF Jr. Repair of gingival defects by a sliding flap operation. J Periodontol 1956; 27:92-5.

6. Grupe HE. Modified technique for the sliding flap operation. J Periodontol 1966;37:491-5.

7. Lee CT, Chang PC, Touchan N, Royzman D. Root coverage with a modified laterally positioned flap combined with a subepithelial connective tissue graft in advanced recession. J Periodontal Implant Sci 2014;44:300-6.

8. Zucchelli G. Mucogingival esthetic surgery. 1st ed. Milano; Quintessenza Edizioni; 2013. p. 330-78.

9. Jahnke PV, Sandifer JB, Gher ME, Gray JL, Richardson AC. Thick free gingival and connective tissue autografts for root coverage. J Periodontol 1993;64:315-22.

10. Carnio J, Neiva RF. Mineral trioxide aggregate and subepithelial connective tissue graft for treatment of iatrogenic gingival recession: long-term results. Int J Periodontics Restorative Dent 2014;34:71-7.

11. Jung UW, Kim CS, Choi SH, Kim S. Gingival cov- erage of iatrogenically denuded labial bone resulting from thermal trauma. Int J Periodontics Restorative Dent 2013;33:635-9.

12. Ruben MP. Rationale for the employment of laterally positioned flaps and free autogenous gingival grafts in periodontics (I). Quintessence Int Dent Dig 1978;9:57-61.

13. Ruben MP. Rationale for the employment of laterally positioned flaps and free autogenous gingival grafts in periodontics (II). Quintessence Int Dent Dig 1978;9:53-7.

14. Hall WB. Gingival augmentation/mucogingival surgery. In: Nevins M, Becker W, Kornman K. Proceedings of the World Workshop in Clinical Periodontics. Chicago; American Academy of Periodontology; 1989. VII 1-21.

15. Santana RB, Furtado MB, Mattos CM, de Mello Fonseca E, Dibart S. Clinical evaluation of singlestage advanced versus rotated flaps in the treatment of gingival recessions. J Periodontol 2010;81:48592.

16. Zucchelli G, Cesari C, Amore C, Montebugnoli L, De Sanctis M. Laterally moved, coronally advanced flap: a modified surgical approach for isolated recession-type defects. J Periodontol 2004;75:173441.

17. Zuhr O, Bäumer D, Hürzeler M. The addition of soft tissue replacement grafts in plastic periodontal and implant surgery: critical elements in design and execution. J Clin Periodontol 2014;41 suppl 15:S123-42.

18. Yotnuengnit P, Promsudthi A, Teparat T, Laohapand P, Yuwaprecha W. Relative connective tissue graft size affects root coverage treatment outcome in the envelope procedure. J Periodontol 2004;75:886-92.

19. Langer B, Langer L. Subepithelial connective tissue graft technique for root coverage. J Periodontol 1985;56:715-20.

20. Miller PD Jr. Root coverage with the free gingival graft. Factors associated with incomplete coverage. J Periodontol 1987;58:674-81. 


\section{상피하결합조직 이식을 동반한 측방변위 판막술을 통한 의원성 치은퇴축 치료 증례보고}

\section{이성조*}

단국대학교 치과대학 치주과학교실

치은퇴축의 원인 중 하나인 의원성 치은퇴축은 교정치료 또는 근관치료에 의하여 발생할 수 있다. 이는 기능적, 심미적 문제뿐만 아니라 치료에 대한 만족도도 낮출 수 있다. 이를 위한 치료 방법으로 다양한 술식이 존재하나, 상피하결합조 직 이식을 동반한 측방변위판막술은 각화치은량의 증대, 치유된 치은의 수여부 연조직과의 조화로운 형태 및 색을 얻을 수 있는 장점이 있다. 술 전 임상적 및 방사선학적 검사를 통한 예지성 있는 적절한 증례 선택을 필요로 하며 술식에 있어 적합한 양의 상피하결합조직 획득과 판막의 피개량을 고려해야 한다. 본 증례보고의 두 가지 다른 원인의 의원성 치은퇴 축의 치료 결과를 살펴보았을 때, 상피하결합조직 이식을 동반한 측방변위판막술은 의원성 치은퇴축의 치료법으로 우수 한 결과를 나타내었으며, 1년 이상의 추적관찰시 높은 예지성을 보였다.

(구강회복응용과학지 2016;32(4):330-7)

주요어: 의원성 질환; 치은퇴축; 판막술; 결합조직; 이식 